\title{
The benefits of reverse logistics
}

\author{
Janusz Grabara ${ }^{1}$, Mariana Man ${ }^{2}$, Michal Kolcun ${ }^{3, *}$ \\ ${ }^{1}$ Czestochowa University of Technology, 69 gen. J. H. Dąbrowskiego St., Częstochowa, Poland \\ ${ }^{3}$ University of Petroşani, 20 Universităţii Street, 332006, Petroşani, Romania \\ ${ }^{3}$ Technical University of Košice, Bayerova 1, 08001, Prešov, Slovakia \\ *E-mail address: mikolcun@yahoo.com
}

\begin{abstract}
In conventional systems of prospect logistics, the flow starts from the raw material provided by suppliers, then manufactured parts and components for assembly of the end product which goes to consumers, and, when fully used can be recycled. The reverse logistics disposed of products eligible for repair, alteration, distribution of the parts, that can be reused as a raw material to be recycled for future use. It also generates the side products (hazardous waste, packaging, etc.). Reverse logistics provides companies with revenues and strategic benefits. Companies whose products are subject to regeneration can save up to $60 \%$ of the estimated cost of a completely new product.
\end{abstract}

Keywords: logistics; reverse logistics; factors; objectives; marketing

\section{INTRODUCTION}

Reverse logistics promotes alternative uses of resources, that can be cost-effective and environmentally friendly by extending the product life cycle. With ecological view of the benefits, organizations as customers are willing to pay more for products that are not harmful to the environment. The importance of reverse logistics practices inspired many manufacturers to design products which can be dismantled and regeneration, in the framework of the sustainable development. Just as in the supply chain, there are three phases of the planning and decision making in reverse logistics systems (Kroon L., \& Vrijens, 1995, pp. 56-68). The design phase (the so-called strategic planning and network design and space allocation) is a longterm decision-making process (over a year), which attempt to modify them is very expensive. This phase requires a decision concerning on the determination of the location of production plants, distribution and collection, determine the products to be manufactured and remanufactured, determine transport routes and establish reimbursement system, marketing strategies, selection of secondary markets and establish supply chain performance measure. In the planning phase (so-called tactical planning), medium-term decisions (six months to a year) are made in policies affecting the production, treatment, inventory, demand uncertainty, exchange rates, etc. In the third and final phase of the operation, decisions on short-term periods (less than six months) are performed (Dowlatshahi, 2000). These relate to everyday activities, such as filling customer orders, 
inventory control, short-term planning, job rotation, etc. Just as in the supply chain, reverse logistics coordination will reduce costs and improve the quality of service (Dima, Grabara \& Pachura, 2010).

\section{THE MAIN ADVANTAGES OF REVERSE LOGISTICS}

The main purpose of reverse logistics is to save (to minimize costs and increase profits). Reverse logistics assures cost-effective alternative materials to replace the original ones, thus saving natural resources, effort and energy. Reverse logistics is an opportunity to recover the value of the returned product, through recovery/reuse/repair process. The share of the dollar in reverse logistics is huge. Logistics represents 9.9 percent of the economy in the United States, as equivalent was 1.3 trillion dollars in 2006. Although reverse logistics is not sufficiently developed to be estimated (Rogers \& Tibben-Lembke, 2009, p. 5), in 1997 reached a value of 35 trillion \$, in 2007 - 56 trillion \$, which is equal to four percent of the total cost of logistics in the United States (Beltran, 2002, pp. 4-8). The advantage of the regeneration of the product, may be shortening the time of delivery, with the demand for spare parts is caused by regeneration of returned products, instead of initiating the redelivery, which implementation will continue much longer (Minner, 2003). For example, in IBM, lease programs significantly reduced the uncertainty of the return flow (Fleischmann, 2001).

\section{Ecologic objectives}

The presence of hazardous toxic materials, such as hexavalent chromium, polybrominated ether, mercury and lead in used electrical components, poses a serious threat to the environment. Twenty-nine states in the U.S. have still ten years of landfill capacity, fifteen states have five to ten years, while the other six states have less than five years. Reverse logistics reduces the amount of waste, deposited in the environment (the materials are reused instead of consuming new resources) by reducing dependence on landfills and energy. Saving energy is another worthy goal ecology. For example, the recycling of aluminum requires only $5 \%$ more energy than processing the same number of primary aluminum ore. Costs unsolicited material sent to landfill, continues to increase, which encourages organizations and businesses to make other economic alternatives to disposal. In addition, many products cannot be longer sent to landfill, as this is prohibited by environmental regulations (Grabara, Kolcun \& Kot, 2014). By implementing reverse logistics, companies save money, reduce energy consumption, emit fewer pollutants into the air and water, save natural resources, reduce waste and avoid waste storage capacity. Some models of reverse logistics functions are considering as multidimensional environmental objectives to improve their environmental performance.

\section{Marketing image objectives}

Many companies today appeal to their customers that they are "environmentally friendly", it is part of their marketing image. The pressure on companies is increasing, as customers began to choose environmentally friendly products. In the past two decades the companies have done their utmost to create eco-profiles, especially in markets dominated by customers, who care about the environment. In addition, companies are responsible for the environmental activities of their suppliers, customers and stakeholders since they have treated their actions as common. For example, in 2005, Dell has increased the level of recovery of 
used computers obtained from their customers by 72 percent compared to 2004, due to recycling and seminars relating to suppliers and customers. Public environmental concern in conjunction with the principle of sustainable development, has created opportunities for organizations to create eco-friendly products that will distinguish them from the competition (Johnson \& Wang, 1988).

\section{Market share and exhibition objectives}

In addition to reducing costs, many organizations take over the products of their competitors, which are used as a supplement to their own products, in order to increase market share. Some companies offer a collection of all brands of the product in exchange for a discount price of its own brand. For example, Dell receives all brands of computers and accessories (eg, keyboard, mouse, monitor or printer) from the door for fee, or offers this service for free, with the purchase of a new Dell computer (Kulwiec, 2009, p. 6).

\section{Assets protection objectives}

High-tech companies encourage their customers to return their products, for fear that technological knowledge may leap to competitors, and to avoid competing with the secondary markets, which can be used to purchase their products. IBM used reverse logistics by recovering valuable part from older products that it can deal with the recycling without the help of intermediaries (Fleischmann, 2009, p. 7).

\section{Objectives of Forrester effect reduction}

In the traditional supply chain, Forrester effect is the gain variation orders in the supply chain from the lowest to the highest level. These are the only studies that discuss the Forrester effect in the context of reverse logistics (Vlăduţescu \& Ciupercă, 2013). The authors showed that the returned products can reduce this effect, by absorbing fluctuations in demand at the beginning of the chain to the extent, that reverse logistics is cheaper than the traditional variable costs, even if the recovery cost is higher than the cost of manufacture of a new product.

\section{FACTORS OF SUCCESSFUL IMPLEMENTATION OF REVERSE LOGISTICS}

Below are described the factors, that are necessary for the successful implementation of reverse logistics and outlines some of the challenges, to be faced during the implementation. In the literature, there are a number of research studies, that relate to these factors and challenges, which makes it attractive for testing of researchers in this field. Some of them exchanged a number of factors (Iancu, Constantinecu \& Colhon, 2010; Colhon, 2013). Almost unanimously found that consumer awareness and legislation are key factors for a successful implementation of reverse logistics. Consumer awareness create legislation, which in turn, leads to a change in consumer behavior. When these two factors are directed to a specific purpose, better results are quickly achieved. According to Ginter and Starling (Ginter \& Starling, 1978), law gave a broader view of the environment at the end of 1960. Established in the U.S., in 1969, National Environmental Policy Act had a major impact on recycling and recovery of waste, by including them in the assessment of the environmental impact of their projects, which gave rise to the creation of recycling projects. One of the first acts presented by the U.S. Congress in 1979 is a law calling for a tax credit for the production and packaging of products for companies that use recycled materials (Guiltinan \& Nwokoye, 1975, p. 28-38). A fine example was observed in the beverage industry, where a large 
consumer sector of the seventies was not sympathetic to giving up the convenience use of a disposable metal cans, in favor of reusable bottles, the cost of which is attractive to manufacturers and distributors. It was estimated that in 1985 in the U.S., $80 \%$ of soft drinks were sold in single cans or bottles. However, environmental concerns had forced strict law, that was one of the few, if not only one output, which allows to solute problem. Guiltinan and Nwokoye (Guiltinan \& Nwokoye, 1975, p. 28-38) confirmed, that support this law, not only makes changes in consumer behavior, but also leads to the fact that manufacturers will soon use biodegradable packaging. By 1990, consumer behavior has changed in the industry in August, because of the growing public concern that the containers are harmful to the environment. This change combined with the bail, which allows customers to return empty bottles (Alter, 1993, p. 166-186.). Due to the mandatory recycling in some cases, for the collection of empty containers retailers are responsible (Dima \& Vlăduţescu, 2012; Vlăduţescu, 2013). Distributors and retailers of beverages in Michigan are authorized by law to collect empty beverage containers for recycling (Goldsby \& Closs, 2000, p. 500-514). Therefore, since 1990, consumer's awareness has become one of the main causes of environmental protection, through the implementation of the return of empty containers. In Europe, the law has been modified to achieve more environmentally friendly projects and processes. In addition, some countries (eg Germany, Denmark and the Netherlands) have introduced taxes on pollution and regulations for the management of waste (Gungor \& Gupta, 1999, p. 811-853).

German Waste Management Act of 1986, stressed the importance of waste reduction and forced the producers to search for new techniques and products, that will minimize loss and promote reuse of waste. Several countries followed in the footsteps of Germany and released the same law. European companies have to redesign their products and their networks to meet the imposed requirements (Dima \& Vlăduţescu, 2013; Vlăduţescu, 2013). WEEE Directive is the legislation, which came into force in February 2003. WEEE restricts the use of hazardous substances in electrical and promote the collection and recycling of such equipment. Manufacturers are obliged to take back their products at the end of its life cycle (Gungor \& Gupta, 1999, p. 811-853). Prendergast discussed the involvement of the European Community (EC) in environmental issues, focusing on the proposed EC Directive on packaging (Prendergast, 1995, p. 10-17). Although the Directive focuses on recycling, also encourages to reduce the amount of packaging and reuse. In 1991, the German packaging ordinance forced companies to receive all sold packaging materials and imposed a minimum percentage of recycling (Fleischmann, Bloemhof-Ruwaard, Dekker, van der Laan, van Nunen, J., \& Van Wassenhove, 1997, pp. 1-17 ). Environmental performance of the company is reflected in the efficiency and effectiveness of product recovery processes. Companies do not need to have specific knowledge of reverse logistics, in order to create sustainable marketing strategies, because environmental groups can help many companies understand environmental issues, develop solutions and implement related strategies and tactics, which are known as "green alliances".

Customer behavior and their relationship to various types of products, have a huge impact on rates of return. For example, in the catalog of retail industry, there is a huge gap between clothing catalogs and electronic catalogs (Traistraru, 2013; Avram \& Traistaru, 2014). Many customers are considering trying out fashion catalogs of products and, therefore, the rate of return is $18-35 \%$ of the delivered goods, while in electronic catalogs, the rate of return is $4-5 \%$ of the delivered goods. Removal of the returned goods from the system of reverse logistics, can be made through the resale of the product in the secondary market or through recycling. The latter form may entail additional costs for the sale of hazardous 
materials. These costs are related to transportation, storage, their ownership and responsibility for it. All parties are responsible for any future orders dumps. A summary of all the activities that can achieve effective reverse logistics is presented below (Giuntini \& Andel, 1995, pp. 93-98):

\section{Design and production:}

$>$ In the early stage of product design, considering his options after the recovery of the life cycle is necessary;

$>$ Redesign of the production process, if necessary;

$>$ The product recovery processes must be compatible with existing processes production;

$>$ Improving or restructuring of a set of materials is essential; 5) Packaging used in reverse logistics should require little effort of materials and costs and should not be difficult to transport.

\section{Process management:}

$>$ Transportation and networks must interact with the current transport system;

$>$ Reducing delivery time mistakes and the amount of the returned goods, this factor in the literature has been devoted to aspecial attention, because caring for him is huge;

$>$ Collecting and analyzing information in order to effectively monitor and control the processes of reverse logistics;

$>$ The prediction and control of the supply of second-hand products;

$>$ Flexibility management policies and procedures;

$>$ The relevant performance metrics to monitor the performance of reverse logistics by collecting information and analysis.

Quality and organization:

$>$ Consumers expect consistent quality from the manufacturer, regardless of the nature of the product, whether new or

$>$ remanufactured, and to determine the quality of their implementation;

$>$ Managers should believe in the importance of reverse logistics;

$>$ Create a sense of ownership among employees is extremely important;

$>$ Establishment of effective leadership and organizational procedures used in reverse logistics is necessary;

Effective implementation and development of ethical standards.

Finance and marketing:

capital investment and long-term commitments are important for recovery programs. Recovery options require an investments, and investments require vision and commitment;

Marketing plans show the efforts of companies to create green image;

$>$ Educational programs for all stakeholders commitment in reverse logistics, including customers;

$>$ Although many companies ensure that the quality of remanufactured parts is the same as newly manufactured items, customers will reach for these new, so in 
order to encourage them to buy recycled products, manufacturers offer lower prices.

\section{CONCLUSIONS}

Companies do not know how many products will be returned to them and what it will be. Reverse logistics let company to prepare for these circumstances, it is better "take care" of them. Companies using reverse logistics, build the image of a responsible company, producing products from recycled materials. Also reduce the generation of debris, and the level of use of non-renewable raw materials, by using the socalled. "Clean technologies" and integrated supply chain.

From the point of viev of offer attractiveness, the recovery of damaged materials and obsolete products, may, in the future, result in the substitution of the original materials. Thus, the method of production would generate lower costs and thus affect the lower price products. All of these activities may affect a sustained competitive advantage for the company ${ }^{56}$.

In addition to the economic and legal reasons, the company introduces to its business principles of reverse logistics for the following reasons (Modrak, Dima, Kot \& Bonaciu, 2011, p. 102):

- Goods in defective condition,

- Returns of excess inventory

- Returns for clients

- Obsolete products

- Season inventories.

The following are the key benefits of the company's strategy of reverse logistics (WIPRO, 2009, p. 9):

- Higher revenues from "secondary" sales, emptying magazines of old stock, by creating space for new ones. Inventories can be managed in such a way to avoid markdowns, with a continuous supply of new stocks to the point of sale. Arrangements to allow the reception of unsold goods from retailers, can be made, to allow for immediately replace them with new ones, to keep the retail price and keep the profit margins.

- Reduce costs by reducing the cost of sales and operating expenses. For some products, the parts can be recycled. As a result, during the regeneration process, additional costs can be avoided. Effects of returns management and processing, also, reduces the costs associated with environmental protection and waste disposal.

- Improved inventory management. To some extent, returned goods can also serve as stock, as well as storage space needed. Effective returns management can help reduce the cost of maintaining the products, that generate profit and reduce the need for storage of products that do not generate a profit.

- Reverse logistics associated with the environmentally friendly operations. Therefore, there is an increasing number of consumers, who choosing the goods, take this factor into account, it allows to gain customer loyalty. 


\section{References}

[1] M. Fleischmann, J. M. Bloemhof-Ruwaard, R. Dekker, E. van der Laan, J. van Nunen, A. Van Wassenhove, L. N. Van Wassenhove, European Journal of Operational Research 103(1) (1997) 1-17.

[2] H. Alter, Journal of Consumer Affairs 27(1) (1993) 166-186.

[3] A. Borowski, International Letters of Social and Humanistic Sciences 14 (2014) 7-17.

[4] Ştefan Vlăduţescu, European Scientific Journal 9(32) (2013).

[4] I. C. Dima, M. Man (2013). Budgeting and Management Control in Industrial Companies. Saarbrucken: LAP Lambert Academic Publishing.

[5] Beltran L. S., Logistics Spectrum 36(3) (2002) 4-8.

[6] S. Dowlatshahi, Interfaces 30(3) (2000) 143-155.

[7] A. Borowski, International Letters of Social and Humanistic Sciences 11 (2014) 1-168.

[8] Ş. Vlăduţescu, E. M. Ciupercă (2013). Next Flood Level of Communication: Social Networks. Aachen: Shaker Verlag.

[9] Alina Ţenescu (2009). Comunicare, sens, discurs. Craiova: Editura Universitaria.

[10] Fleischmann M., Quantitative Models for Reverse Logistics, Berlin Heidelberg: Springer Verlag 2001, [in:] A. MA El Saadany, Inventory management in reverse logistics with imperfect production, learning, lost sales, subassemblies, and price/quality considerations, These and dissertations, Paper 1066, 2009, p. 7.

[11] V. Modrak, I. C. Dima, S. Kot, M. Bonaciu (2011). Systemic Concept of Company's Logistics, W:CECOL 2011. Proceedings of the II Central European Conference on Logistics 2011. Ed. by Maria Nowicka-Skowron. October 20 - 21, 2011, Częstochowa.

[12] A. Borowski, International Letters of Social and Humanistic Sciences 3 (2013) 69-74.

[13] Marian Siminică, Aurelia Traistaru, International Journal of Education and Research 1(12) 2013.

[14] Ioan Constantin Dima, Ştefan Vlăduțescu (2012). The Environment of Organizational Entities and its Influence on Decisional Communication. International.

[15] I. C. Dima, J. Grabara, P. Pachura Polish Journal of Management Studies 1 (2010).

[16] S. Minner, International Journal of Production Economic 81-82 (2003) 265-279.

[17] M. J. Polonsky, S. J. Rosenberger III, Business Horizons 44(5) (2001) 21-30.

[18] S. M. Ginter, J. M. Starling, California Management Review 20 (3) 1978 72-82.

[19] G. S. Prendergast, Logistics Information Management 8(3) (1995) 10-17.

[20] Ştefan Vlăduţescu (2013). What Kind of Communication Is Philosophy. Jokull.

[21] Ioan Constantin Dima (2013). Organisational strategies - a systemic approach - on the example of the automotive industry. Saarbrucken: LAP Lambert Academic Publishing.

[19] A. Borowski, International Letters of Social and Humanistic Sciences 4 (2013) 70-74. 
[20] Aurelia Traistaru, Elena Antoanela Cotoc (2013). Archiving, Keeping Records and Financial Accounting Documents. International.

[21] I. C. Dima (2013). Industrial Production Management in Flexible Manufacturing Systems. IGI Global USA.

[22] R. Giuntini, T. Andel, Transportation \& Distribution 36(3) (1995) 93-98.

[23] A. Borowski, International Letters of Social and Humanistic Sciences 2 (2014) 110-121.

[24] Ştefan Vlăduţescu (2014). Eight computational-communicative operations of building information. Mitteilungen Klosterneuburg.

[25] Aurelia Traistaru (2013). The components of economic record and the research object of Accounting. European.

[26] Ioan Constantin Dima, Ştefan Vlăduţescu (2012). Persuasion elements used in logistical negotiation: Persuasive logistical negotiation. Saarbrucken: LAP Lambert Academic Publishing.

[27] M. G. Mangra, E. A. Cotoc, A. Traistaru, Journal of Studies in Social Sciences 6(1) (2013).

[28] T. J. Goldsby, D. J. Closs, International Journal of Physical Distribution \& Logistics Management 30(6) (2000) 500-514.

[29] Marioara Avram, Aurelia Traistaru, International Letters of Social and Humanistic Sciences 13 (2014) 79-88.

[30] S. Vachon, R. D. Klassen, S. F. Johnson (2001). Customers as green suppliers: managing the complexity of the reverse supply chain, Richard Ivey School of Business, Working Paper Series, No. 2000-02.

[31] F. Smarandache, Ş. Vlăduţescu (2014). Neutrosophic Emergences and Incidences in Communication and Information. Saarbrucken: LAP Lambert Academic Publishing.

[32] Janusz Grabara, Michal Kolcun, Sebastian Kot (2014). The Role of Information Systems in Transport Logistics. International.

[33] I. C. Dima, Ş. Vlăduţescu (2012). Persuasive communication in logistic negotiation. International.

[34] L. Zhou, S. M. Disney, C. S. Lalwani, H. Wu (2004). Reverse logistics: a study of bullwhip in continuous time. Fifth World Congress on Intelligent Control and Automation, Hangrhou, S.R. China, 2004. WCICA 2004, s. 4.3539-4.3542.

[35] I. C. Dima, M. Man, Ş. Vlăduțescu (2012). The Company's Logistic Activity in the Conditions of Current Globalisation. In H. Cuadra-Montiel (Ed.), Globalization, Education and Management Agendas (pp. 263-294). Rijeka: Intech.

[36] M. R. Johnson, M. H. Wang, International Journal of Production Research 36(12) (1988) 3227-3252.

[37] A. Gungor, S. M. Gupta, Computers and Industrial Engineering 36(4) (1999) 811-853. 
[38] J. S. Guiltinan, N. G. Nwokoye, International Journal of Physical Distribution \& Logistics Management 6(1) (1975) 28-38.

[39] F. Smarandache, Ş. Vlăduțescu (2013). Communication vs. Information, a Neutrosophic Solution. Neutrosophic Sets and Systems.

[40] Bianca Teodorescu, International Letters of Social and Humanistic Sciences 12 (2014) 73-78.

[41] A. Borowski, International Letters of Social and Humanistic Sciences 6 (2013) 86-90.

[42] I. C. Dima, Ş. Vlăduţescu (2013). Some consequences of the negative journalistic communication in the austerity periods. Science Series Data Report.

[43] Aurelia Traistaru, Jokull 63(9) 2013 125-135.

[44] Ştefan Vlăduţescu, International Letters of Social and Humanistic Sciences 10(2) (2014) 100-106.

[45] Cerasela Vintilescu, International Letters of Social and Humanistic Sciences 13 (2014) 58-63.

[46] L. Kroon, G., Vrijens, International Journal of Physical Distribution \& Logistics Management 25(2) (1995) 56-68.

[47] Kulwiec, R., Reverse Logistics Provides Green Benefits. Association for Manufacturing Excellence 2006, [in:] A. MA El Saadany, Inventory management in reverse logistics with imperfect production, learning, lost sales, subassemblies, and price/quality considerations, These and dissertations, Paper 1066, 2009.

[48] Ştefan Vlăduţescu (2013). Principle of the Irrepressible Emergence of the Message. Jokull.

[49] A. Borowski, International Letters of Social and Humanistic Sciences 3 (2013) 46-53

[50] WIPRO (2009). Reverse Logistics Management - Am Effective Strategy for Revenue Maximanization in CPG Industry.

[51] Colhon M. (2013). Automatic Lexical Alignment between Syntactically Weak Related Languages. Application for English and Romanian. In Computational Collective Intelligence. Technologies and Applications (pp. 266-275). Springer Berlin Heidelberg.

[52] I. Iancu, N. Constantinescu, M. Colhon, International Journal of Computers Communications \& Control 4(5) (2010) 525-531.

[53] Sandu Frunză (2014). Advertising and Administration under the Pressure of Ethics. Les Arcs: Editions de la Suers.

[54] N. Munteanu (2013). The Influence of Media Communication on the Military Organizations. Buletin Stiintific.

[55] Cerasela Vintilescu, International Letters of Social and Humanistic Sciences 13 (2014) 58-63.

[56] T. Lis, Paula Bajdor (2013). Sales Logistics as a Model Used by Companies Fulfilling Individual Customer's Needs. In: Challenges in Contemporary Management.

Monograph. Scientific Editors Anna Lemańska-Majdzik, Piotr Tomski, Sekcja Wydaw. WZ PCzęst, Czestochowa. 
[57] Rajesh K. Yadav, International Letters of Social and Humanistic Sciences 10(2) (2014) 84-90.

[58] Jacek Tittenbrun, International Letters of Social and Humanistic Sciences 9 (2014) $26-48$.

[59] Jason L. Powell, International Letters of Social and Humanistic Sciences 7 (2014) 22-30. 